\title{
Use of Essential Oils of the Genus Citrus as Biocidal Agents
}

\author{
Marcos S. Gomes ${ }^{1}$, Maria das G. Cardoso ${ }^{1 *}$, Maurilio J. Soares ${ }^{2}$, Luís R. Batista ${ }^{3}$, \\ Samísia M. F. Machado ${ }^{4}$, Milene A. Andrade ${ }^{1}$, Camila M. O. de Azeredo ${ }^{2}$, \\ Juliana Maria Valério Resende ${ }^{3}$, Leonardo M. A. Rodrigues ${ }^{3}$ \\ ${ }^{1}$ Department of Chemistry, Federal University of Lavras, Lavras, Brazil; ${ }^{2}$ Laboratory of Cell Biology, Instituto Carlos Cha- \\ gas/Fiocruz, Curitiba, Brasil; ${ }^{3}$ Department of Food Science, Federal University of Lavras, Lavras, Brazil; ${ }^{4}$ Department of Chemistry, \\ Federal University of Sergipe, São Cristóvão, Brazil. \\ Email: *
}

Received November $26^{\text {th }}, 2013$; revised December $28^{\text {th }}, 2013$; accepted January $18^{\text {th }}, 2014$

Copyright (C) 2014 Marcos S. Gomes et al. This is an open access article distributed under the Creative Commons Attribution License, which permits unrestricted use, distribution, and reproduction in any medium, provided the original work is properly cited. In accordance of the Creative Commons Attribution License all Copyrights (C) 2014 are reserved for SCIRP and the owner of the intellectual property Marcos S. Gomes et al. All Copyright @ 2014 are guarded by law and by SCIRP as a guardian.

\section{ABSTRACT}

In this study, the essential oils extracted from the peels of Citrus aurantifolia, Citrus limon and Citrus sinensis were chemically characterized and quantified. These essential oils and their standards limonene, citral and limonene + citral were evaluated (at concentrations ranging from 500 to $3.91 \mathrm{~mL} \cdot \mathrm{mL}^{-1}$ ) regarding their anti-trypanosome, antifungal and antibacterial activities. The chemical identification and quantification (by GC/FID and GC/MS) displayed the limonene as the major component of the three essential oils. It did not verified antitrypanosome activity for all treatments. Regarding antimicrobial activity, the results were satisfactory against Gram-negative bacteria (Staphylococcus aureus, Listeria. monocytogenes and Salmonella cholerasuis) and funghi (Aspergillus niger, A. flavus and A. carbonarius), except for the bacterium Pseudomonas aeruginosa, which showed no inhibition for any treatment used.

\section{KEYWORDS}

Volatile Essential Oil; Trypanosoma cruzi; Gram-Negative Bactéria; Funghi; Antimicrobial

\section{Introduction}

Human civilization has been using plants with therapeutic properties for centuries and these natural products nowadays have been used in the development of new drugs in the Pharmaceutical area. Among the compounds used to produce these drugs, the secondary metabolites have been raised as one of the most important molecules. In this context, we highlight the essential oils, which are mixtures of several volatile compounds being insoluble in water, soluble in organic solvents and showing great therapeutic importance [1].

In recent decades, the antimicrobials of traditional plants have received great attention due to the resistance to commercial antibiotics developed by some microorganism [2,3]. An alternative to reduce the microorganism growth is using essential oils with antifungal and anti-

\footnotetext{
"Corresponding author.
}

bacterial properties [4-7]. It has been reported that the antimicrobial properties of essential oils are due to hydrophobic characteristic of the chemical constituents of their composition [8]. The lipophilicity of the essential oil allows interaction among their constituents with lipids in the cell membrane, affecting the cell permeability and causing changes in cell structure [9].

Despite recent advances in antimicrobial chemotherapy, the treatment of parasitic diseases has remained as a public health problem highlighting the Chagas disease [10]. This disease is caused by the protozoan parasite Trypanosoma cruzi, causing approximately 50,000 deaths per year [11]. In recent years, the use of essential oils has acquired great importance for the treatment of parasitic diseases [12,13].

The development of new effective drugs against parasitic disease (i.e. Chagas disease) has been aimed for several researchers, because most of the synthetic com- 
pounds used to treat these parasitic diseases produce toxicity and side effects for the patients. Moreover, there has been a need to find more effective compounds with antimicrobial effect to reduce the contamination and deterioration of food.

Thus, in this study we aimed to characterize and chemically quantify the essential oils extracted from the peels of lime (Citrus aurantifolia), limon (Citrus limon) and orange (Citrus sinensis), as well as to evaluate, with standards limonene, citral and limonene + citral, the antitrypanosome, antifungal and antibacterial activities.

\section{Material and Methods}

\subsection{Collect of the Vegetal Material and Extraction of the Essential Oil}

The vegetal materials, lime (C. aurantifolia), lemon (C. limon) and orange (C. sinensis), were collected on a rural area of Lavras city in the morning during the months of March and April 2012, at coordinates 21 $26^{\prime} 27$ south and $44^{\circ} 39 ' 27$ west, with an altitude of 1049 meters.

The extraction process of the essential oils was performed at Laboratory of Organic Chemistry of the Department of Chemistry at Federal University of Lavras. The method used was the hydrodistillation, using a modified Clevenger device [14]. Extractions were performed in triplicate for a period of 2 hours and their yields have been calculated on moisture free basis. Moisture was performed using the technique described by [4], using the Dean Stark type glass collector. The humidity was calculated considering the water content in $100 \mathrm{~g}$ of sample.

\subsection{Chemical Identification and Quantification of the Essential Oils}

The quantitative analysis and the identification of constituents of the essential oils were performed at the Department of Chemistry at Federal University of Sergipe. The quantitative analyses of the reaction mixture were performed in a gas chromatography equipped with a flame ionization detector (Shimadzu GC-17A), under the following operational conditions: fused silica capillary column ZB-5MS (5\% dimethylpolysiloxane) with $30 \mathrm{~m} \times$ $0.25 \mathrm{~mm}$ i.d. $\times 0.25 \mu \mathrm{m}$ of film, using $\mathrm{He}$ as gas carrier with flow of $1.2 \mathrm{~mL} \cdot \mathrm{min}^{-1}$. The temperature was kept at $50^{\circ} \mathrm{C}$ for 2 minutes, and later increased $4^{\circ} \mathrm{C} \mathrm{min}{ }^{-1}$, up to reaching $200^{\circ} \mathrm{C}$. After that, increased $15^{\circ} \mathrm{C} \mathrm{min}{ }^{-1}$, up to reaching $300^{\circ} \mathrm{C}$, keeping this temperature steady for 15 minutes; the temperature of the injector was $250^{\circ} \mathrm{C}$ and the temperature of the detector (or interface), $280^{\circ} \mathrm{C}$. It was injected a volume of $0.5 \mu \mathrm{L}$ of the reaction mixture dissolved in ethyl acetate. The qualitative analysis of the reaction mixture was performed in gas chromatography coupled to a mass spectrometry CG-EM (Shimadzu, model QP 5050A), equipped with fused silica capillary column (J\&W Scientific; 5\%-phenyl-95\%-dimethylpolysiloxane) $30 \mathrm{~m} \times 0.25 \mathrm{~mm}$ i.d., $0.25 \mu \mathrm{m}$ of film, using $\mathrm{He}$ as gas carrier, with flow of $1.2 \mathrm{~mL} \cdot \mathrm{min}^{-1}$. The chromatographic conditions of the analysis were the same used for CG-DIC. The conditions of the EM were detector of ionic capture operating by electronic impact and impact energy of $70 \mathrm{eV}$; scan rate 1.000; interval of decomposition of 0.50 fragments/s and detected fragments in the stripe from 40 to $500 \mathrm{Da}$. For the identification of the constituents, it was also used the comparison of their retention indexes with the ones of the literature [15]. For the retention index, the equation of Van den Dool and Kratz (1963) was used in relation to a homologous series of n-alkanes $\left(\mathrm{nC}_{9}-\mathrm{nC}_{18}\right)$. Two libraries NIST107 and NIST21 were also used, which allowed comparison of the spectra database with the ones in the libraries.

\subsection{Evaluation of the Anti-Trypanosome in Vitro Activity}

First, confirm that you have the correct template for your paper size. This template has been tailored for output on the custom paper size $(21 \mathrm{~cm} \times 28.5 \mathrm{~cm})$. Evaluation of the anti-trypanosome activity of the essential oils, citral and limonene standards and their mixture (limonene + citral) were performed at the Instituto Carlos Chagas/ Fiocruz, Curitiba, Paraná. Three-day-old culture epimastigote forms of Trypanosoma cruzi strain Dm28c were used in all experiments. The parasites were kept at $28^{\circ} \mathrm{C}$ in LIT (liver Infusion Tryptose) medium supplemented with $10 \%$ fetal calf serum.

The essential oils were initially dissolved in dimethyl sulphoxide (DMSO) at a concentration of $100 \mathrm{mg} \cdot \mathrm{mL}^{-1}$. This solution was then dissolved in culture medium to obtain a stock solution at $1 \mathrm{mg} \cdot \mathrm{mL}^{-1}$. Under this condition, the DMSO was diluted at $0.01 \%$, a concentration that is not toxic for the protozoa. Both solutions were stored at $-20^{\circ} \mathrm{C}$. The stock solution was then diluted at different concentrations for the experiments (500; 250; 125 ; 62.5 ; 31.25; $15.63 ; 7.81 ; 3.91 \mu \mathrm{g} \cdot \mathrm{mL}^{-1}$ ) in $20 \mu \mathrm{L}$ of LIT medium in each well of 96-wells plates. After dilution, it was added $180 \mu \mathrm{L}$ of culture medium with epimastigote per well, at a concentration of $1 \times 10^{7}$ parasites $\mathrm{mL}^{-1}$. In control wells were added $200 \mu \mathrm{L}$ of culture medium with parasites, but without treatment. The plates were incubated for 24 hours at $28^{\circ} \mathrm{C}$.

After incubation, $50 \mu \mathrm{L}$ of MTT (3-(4,5-methyl-thiazol-2-yl)-2,5-diphenyltetrazolium bromide) solubilized at $10 \mathrm{mg} \cdot \mathrm{mL}^{-1}$ in PBS (phosphate buffered saline, $\mathrm{pH} 7.2$ ) was added to all wells. The plate was wrapped in aluminum foil and incubated for 3 hours at $28^{\circ} \mathrm{C}$ [16]. After this second incubation, $50 \mu \mathrm{L}$ of paraformaldehyde (4\%) in PBS pH 7.2 were added and the plate was centrifuged 
at $1700 \mathrm{rpm}$ for 10 minutes. The medium was removed by quickly inverting the plate and the parasites were resuspended by gently tapping the plate. Twenty $\mu \mathrm{L}$ of SDS (sodium dodecyl sulfate, at $10 \%$ in $0.01 \mathrm{M} \mathrm{HCl}$ ) were added and the plate was incubated at $37^{\circ} \mathrm{C}$ for 1 hour, or until lysis of all parasites. Subsequently, $80 \mu \mathrm{L}$ of DMSO were added to all wells to solubilize the formazan crystals, by incubating the plate at $37^{\circ} \mathrm{C}$ under shaking until complete solubilization of the crystals. The absorbance reading was performed at $550 \mathrm{~nm}$ in an ELISA reader.

The percent cell death of epimastigotes (ECD) was determined by the equation \%ECD $=[100($ Ac-As) $] / A c]$, where ECD\% is the percentage of epimastigote cell death, Ac is absorbance of control, and As is absorbance of the sample.

\subsection{Evaluation of Antibacterial and Antifungal Activities in Vitro}

Evaluations of antibacterial and antifungal activity of essential oils (from C. aurantifolia, C. limon and C. sinensis), citral and limonene standards and their mixture (limonene + citral) were performed at the Laboratory for Mycotoxin and Mycology, Department of Science food, Federal University of Lavras. The microorganisms used were Pseudomonas aeruginosa ATCC 15442, Salmonella cholerasuis ATCC 6539, Listeria monocytogenes ATCC 19117, Staphylococcus aureus ATCC 13565, Aspergillus niger, Aspergillus flavus and Aspergillus carbonarius.

The bacteria sensibility against essential oils and their standards was determined using the agar diffusion test. After activation of the bacteria in BHI (Brain Heart Infusion) broth, aliquots of the medium were transferred to a tube containing $5 \mathrm{ml}$ of tryptic soy broth (TSB). The tubes were incubated at $37^{\circ} \mathrm{C}$ until reaching the turbidity of a McFarland standard solution of 0.5 , resulting in a suspension containing $10^{8} \mathrm{CFU} \mathrm{mL}^{-1}$. The turbidity readings were performed using a spectrophotometer (Shimadzu UV-160 PC 1) at a wavelength of $625 \mathrm{~nm}$, according to the standards imposed by the National Committee for Clinical Laboratory Standards [17].

The inoculum concentration obtained by the McFarland standard solution was diluted in TSB to give a concentration of $10^{6} \mathrm{CFU} \mathrm{mL}{ }^{-1}$. This inoculums was subsequently transferred to a Mueller-Hinton agar, by pouring it over a thin layer of agar containing glass beads. After cooling the medium, the beads were removed with help of sterile tweezers, forming wells that were filled with 10 $\mu \mathrm{L}$ of essential oils or their standards diluted in dimethylsulfoxide (DMSO) at concentrations of 500, 250, 125, 62.5, 31.25, 15.63, 7.81 and $3.91 \mathrm{~mL} \cdot \mathrm{mL}^{-1}$.

As a positive control, $10 \mu \mathrm{L}$ of chloramphenicol (1 $\mathrm{g} \cdot \mathrm{L}^{-1}$ ) were placed in a well, while the same amount of dimethylsulfoxide (DMSO) was used as a negative control. The plates were incubated at $37^{\circ} \mathrm{C}$ for 24 hours and then the circumferences of the halos formed for each treatment were measured. The minimum inhibitory concentration (MIC) was defined as the lowest concentration of the essential oil and standards where an inhibition halo was formed [18].

To evaluate the inhibitory effect on filamentous fungi, we used the disk diffusion test accepted by the US Food and Drug Administration (FDA) and established as standard by the National Committee for Clinical Laboratory Standards [18]. A concentration of $10^{6}$ spores $\mathrm{mL}^{-1}$ was used for the experiments, with countings in a Neubauer chamber. This inoculum was transferred to a plate containing malt extract agar (MEA), using the surface scattering technique. Filter paper disks of $6 \mathrm{~mm}$ in diameter were placed onto the culture medium and were embedded with $10 \mu \mathrm{L}$ of essential oils or standards diluted in DMSO, at concentrations of 500, 250, 125, 62.5, 31.25, $15.63,7.81$, and $3.91 \mu \mathrm{L} \cdot \mathrm{mL}^{-1}$. As a positive control, 10 $\mu \mathrm{L}$ of $2 \%$ hypochlorite $\left(1 \mathrm{~g} \cdot \mathrm{L}^{-1}\right)$ were deposited in a well, while the same amount of DMSO was used as a negative control. The plates were incubated in BOD at $25^{\circ} \mathrm{C}$ for 72 hours and then the minimum inhibitory concentration (MIC) was defined as the lowest concentration of essential oil where the presence of an inhibition zone could be identified.

\subsection{Statistics Analysis}

For evaluation of the anti-trypanosome in vitro activity the experiments were arranged in a completely randomized design $(\mathrm{CRD})$ in factorial $(6 \times 8)$, 6 samples $(3$ essential oils, 2 standards and their mixture) and 8 concentrations. Data were submitted to analysis of variance (3 replicates) and quantitative variables with $\mathrm{F}$ significance were submitted to regression analysis. Statistical analyzes were performed by using the Statistical Analysis System program of Variance for Balanced Data-Sisvar, according to Ferreira (2008) [19]. The $\mathrm{IC}_{50}$ (concentration effective for $50 \%$ growth inhibition of epimastigote cells) was estimated by the regression equation analyzed using the software Origin 8.

\section{Results and Discussion}

\subsection{Yield, Identification and Chemical Quantification of Essential Oil Oils}

The mean values of the essential oil (EO) content of lime, lemon and orange peels in moisture free basis were $2.2 \%$, $2.2 \%$ and $1.1 \%$, respectively. The chemical constituents of the essential oils, as analyzed by gas chromatography coupled to mass spectrometry (GC/MS), are shown in Table 1, demonstrating a variety of constituents. These results are in agreement with those of Ladaniya (2008) 
Table 1. Identification and quantification of peel essential oils from lime, lemon and orange.

\begin{tabular}{|c|c|c|c|c|c|}
\hline Compoud & IR cal. & IR lit. & LI \% & LE\% & OR\% \\
\hline Triciclene & 922 & 926 & 2.24 & 2.35 & 4.16 \\
\hline Sabinene & 975 & 975 & 1.51 & 7.51 & 2.50 \\
\hline$\beta$-pinene & 975 & 979 & 6.82 & - & 6.67 \\
\hline Myrcene & 989 & 990 & 1.84 & 1.64 & 2.92 \\
\hline Octanal & 1006 & 998 & - & 0.78 & 1.69 \\
\hline p-cymene & 1026 & 1024 & 1.17 & - & - \\
\hline Limonene & 1031 & 1029 & 52.11 & 52.62 & 76.00 \\
\hline$\gamma$-terpinene & 1060 & 1059 & 7.28 & 3.44 & 1.89 \\
\hline Linalol & 1103 & 1096 & - & 2.03 & 4.17 \\
\hline Terpinen-4-ol & 1184 & 1177 & - & 1.17 & - \\
\hline$\alpha$-terpineol & 1199 & 1188 & 2.02 & 3.05 & - \\
\hline Neral & 1241 & 1238 & 4.41 & 5.47 & - \\
\hline Geranial & 1271 & 1267 & 6.73 & 7.89 & - \\
\hline Neril acetate & 1361 & 1361 & 3.14 & 2.03 & - \\
\hline Geranil Acetate & 1380 & 1381 & 1.16 & 1.64 & - \\
\hline$\alpha$-trans-bergamotene & 1436 & 1434 & 2.22 & - & - \\
\hline$\beta$-bisabolene & 1511 & 1505 & 4.26 & - & - \\
\hline Total (\%) & & & $96.91 \%$ & $91.62 \%$ & $100.00 \%$ \\
\hline
\end{tabular}

IR cal.—Kovats index calculated (ADAMS, 2007); IR lit.—Retention index of literature; LI—Lime; LE—Lemon; OR—Orange.

[20] that described the existence of more than 150 compounds in essential oils of the genus Citrus. It was observed in all essential oils that limonene was the major component, with the highest concentration in orange (76.0\%), followed by lemon (52.6\%) and lime (52.1\%). The compound citral (isomeric mixture of geranial and neral) was also found in higher amounts in the essential oils of lemon (13.3\%) followed by lime (11.1\%). This compound has been found as the main component for the aroma and quality of citrus essential oils [20].

\subsection{Anti-Trypanosome Activity in Vitro}

The variance analysis showed significant interaction $(\mathrm{P}<$ 0.05 ) among the samples and concentrations. Viability varied significantly among the samples, but for each concentration it could be observed a dose-dependent effect (Figure 1). Regression analysis showed that the $\mathrm{IC}_{50}$ of the standard limonene was the lowest $\left(308.0 \mathrm{mg} \cdot \mathrm{mL}^{-1}\right.$ ) followed by citral $\left(323.0 \mathrm{mg} \cdot \mathrm{ml}^{-1}\right)$, the mixture $(379.6$ $\left.\mathrm{mg} \cdot \mathrm{mL}^{-1}\right)$, the orange EO $\left(560.8 \mathrm{mg} \cdot \mathrm{mL}^{-1}\right)$, the lime EO (584.5 $\mathrm{mg} \cdot \mathrm{mL}^{-1}$ ) and finally the lemon EO (618.5 $\left.\mathrm{mg} \cdot \mathrm{mL}^{-1}\right)$. According to standards proposed by Muthaura et al. (2007) [21], the trypanocidal activity found was absent, since an $\mathrm{IC}_{50}$ value less than $10 \mathrm{mg} \cdot \mathrm{mL}^{-1}$ can be considered high activity, between 10 and $20 \mathrm{mg} \cdot \mathrm{mL}^{-1}$ can be considered moderate and between 20 and 100 $\mathrm{mg} \cdot \mathrm{mL}^{-1}$ can be considered weak. The standards and their mixture presented similar $\mathrm{IC}_{50}$ values and a syner- gistic effect could not be observed between citral and limonene. However, the isolated constituents were more active than the essential oils.

In accordance to our results, Santoro et al. (2007) [12] noted a dose-dependent effect when analyzing the activity of the essential oils of clove, basil, yarrow and their major constituents (eugenol and linalool) against epimastigote form of $T$. cruzi. The authors also observed that the trypanocidal activity was weak, with $\mathrm{IC}_{50}$ of the five treatments varying from 99.5 to $246.0 \mathrm{mg} \cdot \mathrm{mL}^{-1}$. In another work, Santoro et al. (2007) [13] found similar results using the essential oil of Cymbopogon citratus and its major component citral, obtaining a dose-dependent effect. Some studies have shown that essential oils have effects against all three forms of $T$. cruzi and this is probably due to essential oil properties such as low density and lipid solubility, which enable them to diffuse across cell membranes and break layers of polysaccharides, fatty acids and phospholipids, while also affecting some organelles and some cytoplasmic metabolic pathways $[2,13,8]$.

\subsection{In Vitro Antimicrobial Activity}

Regarding antibacterial activity, as observed by the IMC, the treatments with citral, mixture of limonene + citral, and the essential oils of lime and lemon resulted in similar satisfactory inhibitory effect against the bacteria $S$. aureus, L. monocytogenes and S. cholerasuis. However, 


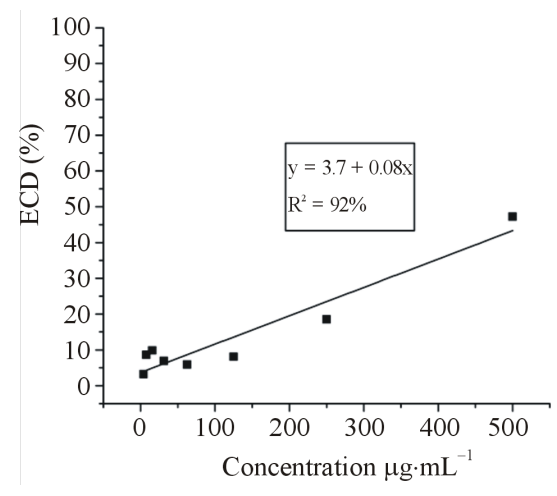

(a)

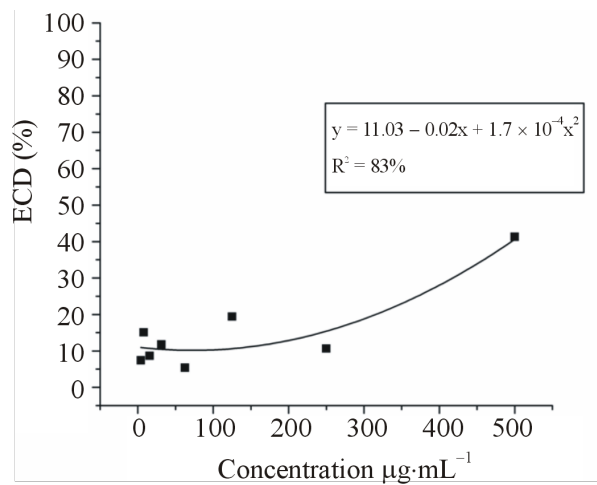

(c)

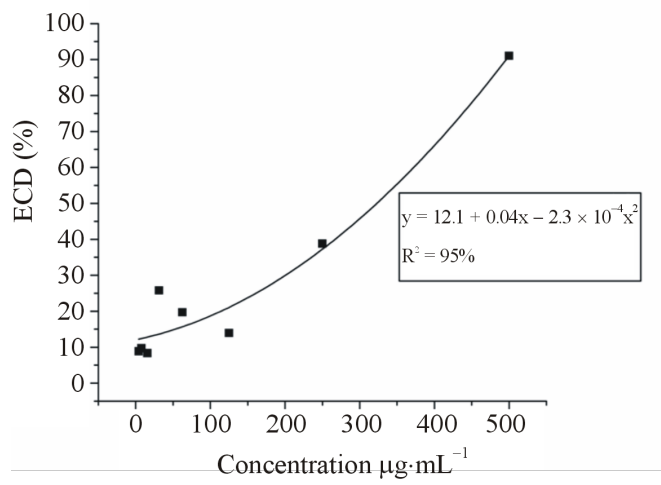

(e)

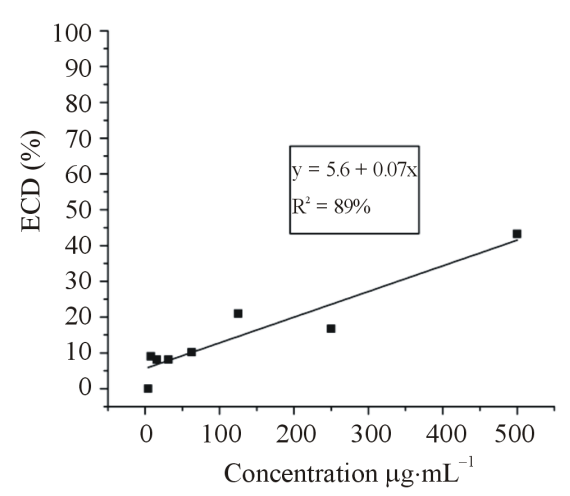

(b)

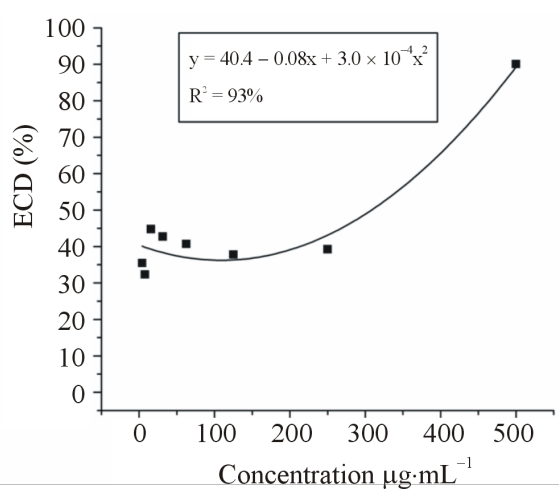

(d)

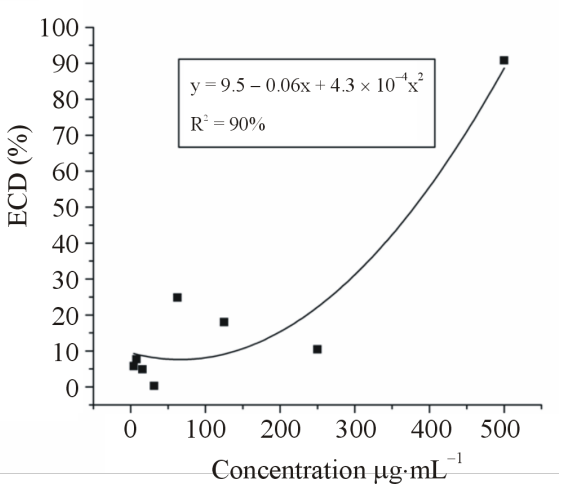

(f)

Figure 1. Anti-trypanosome activity of three essential oils of the genus Citrus and the standards citral, limonene and the mixture (limonene + citral) on T. cruzi epimastigote forms. (a) Lime (b) Lemon (c) Orange (d) Limonene (e) Citral and (f) mixture (limonene + citral). Legend: ECD\% = Percentage of epimastigotes cell death.

the essential oil of lime showed no inhibition against the bacteria $S$. cholerasuis, while the standard limonene and the orange essential oil showed inhibition only for the bacterium $S$. aureus. Among all bacteria studied $P$. aeruginosa was the most resistant against the treatments, with no inhibitory activity. The negative control, the diluent DMSO, showed no interference in activity of essential oils and standards, without inhibition halo formation. As for the positive control, chloramphenicol (1 $g \cdot L^{-1}$ ), there was inhibition halo formation, which was greater than the halos in the treatments tested (Table 2).
Several studies have investigated the action of essential oils on Gram-positive and Gram-negative bacteria, indicating that they are more active against Gram-positive bacteria [5]. Accordingly, we found that Gram-positive bacteria ( $S$. aureus and $L$. monocytogenes) were more susceptible to treatment than Gram-negative bacteria. This could be explained because Gram-negative species have an outer membrane that provides a surface hydrophilicity due to the presence of lipopolysaccharides, thus hindering the access of essential oils, which are mostly constituted of hydrophobic compounds [22]. 
Table 2. Minimum inhibitory concentration of essential oils of lime, lemon, orange and the standards citral, limonene and limonene + citral against microorganisms $S$. aureus, $L$. monocytogenes, $P$. aeruginosa and $S$. cholerasuis.

\begin{tabular}{ccccccc}
\hline \multirow{2}{*}{ Bacterium } & \multicolumn{6}{c}{ IMC $\left(\boldsymbol{\mu g} \cdot \mathbf{m L}^{-1}\right)$} \\
\cline { 2 - 7 } & LI & LE & OR & C & L & C + L \\
\hline S.a. & 7.81 & 7.81 & NI & 3.91 & 500 & 3.91 \\
L.m. & 3.91 & 3.91 & NI & 3.91 & NI & 3.91 \\
P.a. & NI & NI & NI & NI & NI & NI \\
S.c. & NI & 62.50 & NI & 15.62 & NI & 15.62 \\
\hline
\end{tabular}

Legend: $\mathrm{NI}=$ no inhibition; $\mathrm{LI}=$ Lime LE $=$ Lemon; $\mathrm{OR}=$ Orange; $\mathrm{C}=$ Citral; L = Limonene; S.a. $=$ S. aureus; L.m. $=$ L. monocytogenes; P.a. $=$ P. aeruginosa; S.c. $=$ S. cholerasuis.

When analyzing the essential oil of the peels of Citrus limon, C. paradisi, C. bergamia, C. aurantium, C. sinensis and C. reticulata Kirbaslar et al. (2009) [23] found limonene as the major component. The authors evaluated the antimicrobial activity of these essential oils against 9 bacteria and found a strong antibacterial activity, more prominent for the essential oil extracted from lemon peels.

Table 3 shows the antifungal activity against three fungi, Aspergillus niger, A. flavus and A. carbonarius, using the disk diffusion method. It was observed through the IMCs that the essential oils of lemon, lime, orange, as well as limonene, citral and the mixture of limonene + citral had similar IMCs values. This might be due to the similar chemichal composition of these essential oils, which show high a concentration of limonene.

Similarly to the results of antibacterial activity, we observed that for the antifungal activity there was no synergistic effect between the standards limonene and citral, since the effect did not increase with the combination. Several studies have reported interactions among substances aiming to potentiate the desired effect (synergism) or decrease it (antagonism). According to Deba et al. (2008) [24] the antimicrobial activity of essential oils is probably due to the presence of a single compound, or synergism, or antagonism among several compounds. To verify the antimicrobial effect against the $S$. cerevisiae yeast, Belleti et al. (2010) [25] used a combination of the compounds citral, linalool and $\beta$-pinene. They found that the antimicrobial activity of these three terpenes increased when they were combined.

\section{Conclusions}

The major compound of essential oils from peels of three species of the genus Citrus was limonene, with $52.1 \%$ for lime essential oil, $52.6 \%$ for the lemon essential oil and $76.0 \%$ for the orange essential oil.

The essential oils of lime, lemon and orange, the limone and citral standards, and standard mixture (limonene +
Table 3. Minimum inhibitory concentration of essential oils of lime, lemon, orange and the standards citral, limonene and limonene + citral against microorganisms A. niger, $A$. flavus and $A$. carbonarius.

\begin{tabular}{ccccccc}
\hline \multirow{2}{*}{ Fungo } & \multicolumn{7}{c}{ IMC $\left(\boldsymbol{\mu g} \cdot \mathbf{m L}^{-\mathbf{1}}\right)$} \\
\cline { 2 - 7 } & LI & LE & OR & C & L & C+L \\
\hline A.n. & 62.5 & 62.5 & 500 & 3.91 & 500 & 3.91 \\
A.f. & 500 & 500 & 250 & 62,5 & 62.5 & 62.5 \\
A.c. & 62.5 & 125 & 500 & 3.91 & 500 & 3.91 \\
\hline
\end{tabular}

Legend: $\mathrm{LI}=$ Lime; $\mathrm{LE}=$ Lemon; $\mathrm{OR}=$ Orange; $\mathrm{C}=$ Citral; $\mathrm{L}=$ Limonene; A.n. $=$ A. niger; A.f. $=$ A. flavus; A.c. $=$ A. carbonarius.

citral) showed no trypanocidal activity. However, the antimicrobial activity against the bacteria $S$. aureus, $L$. monocytogenes and S. cholerasuis was satisfactory.

\section{Acknowledgements}

The authors acknowledge the support of Conselho Nacional de Desenvolvimento Científico e Tecnológico (CNPq), Coordenação de Aperfeiçoamento de Pessoal de Nível Superior (CAPES), Fundação de Amparo e Pesquisa do Estado de Minas Gerais (FAPEMIG) and Fiocruz in the form of scholarships and financial support.

\section{REFERENCES}

[1] C. M. O. Simões, E. P. Schenkel, G. Gosmann, J. C. P. Mello, L. A. Mentz and P. R. Petrovick, "Farmacognosia: Da Planta ao Medicamento,” 6th Edition, Federal University of Rio Grande do Sul, Porto Alegre, 2007.

[2] T. G. Santos, et al., “Composição Química e Avaliação da Atividade Antimicrobiana do Óleo Essencial das Folhas de Piper malacophyllum (C. Presl.) C. DC,” Quimica Nova, Vol. 35, No. 3, 2012, pp. 477-481. http://dx.doi.org/10.1590/S0100-40422012000300007

[3] A. Kamran, R. K. Mishra, R. Gupta, A. Kumar, A. K. Bajaj and A. Dikshit, "Therapeutic Effects of Essential Oil from Waste Leaves of Psidium guajava L. against Cosmetic Embarrassment Using Phylogenetic Approach,” American Journal of Plant Sciences, Vol. 3, No. 6, 2012, pp. 745-752. http://dx.doi.org/10.4236/ajps.2012.36090

[4] F. A. Pimentel, M. G. Cardoso, L. R. Batista, L. G. L. Guimarães and D. M. Silva, "Ação Fungitóxica do Óleo Essencial de Tanaecium nocturnum (Barb. Rodr.) Bur. e K. Shum Sobre o Aspergillus flavus Isolado da Castanha-Do-Brasil (Bertholletia excelsa)," Acta Amazônica, Vol. 40, No. 1, 2010, pp. 213-220.

http://dx.doi.org/10.1590/S0044-59672010000100027

[5] M. A. Andrade, M. G. Cardoso, L. R. Batista, A. C. T. Mallet and S. M. F. Machado, "Óleos Essenciais de Cymbopogon nardus, Cinnamomum zeylanicum e Zingiber officinale: Composição, Atividades Antioxidante e Antibacteriana,” Revista Ciência Agronômica, Vol. 43, No. 2, 2012, pp. 399-408.

http://dx.doi.org/10.1590/S1806-66902012000200025

[6] W. Okunowo, O. Oyedeji, L. Afolabi and E. Matanmi, 
"Essential Oil of Grape Fruit (Citrus paradisi) Peels and Its Antimicrobial Activities,” American Journal of Plant Sciences, Vol. 4, No. 7A2, 2013, pp. 1-9. http://dx.doi.org/10.4236/ajps.2013.47A2001

[7] M. S. Gomes, et al., "Multivariate Analysis of the Essential Oil Components of the Genus Citrus and Their Antifungal Activity,” Científica, Jaboticabal, Vol. 41, No. 2, 2013, pp. 111-121.

[8] F. Bakkali, S. Averbeck, D. Averbeck and M. Idaomar, "Biological Effects of Essential Oils," Food and Chemical Toxicology, Oxford, Vol. 46, No. 2, 2008, pp. 446-475. http://dx.doi.org/10.1016/j.fct.2007.09.106

[9] A. R. T. Costa, et al., "Ação do Óleo Essencial de Syzygium aromaticum (L.) Merr. \& L. M. Perry Sobre as Hifas de Alguns Fungos Fitopatogênicos,” Revista Brasileira de Plantas Medicinais, Vol. 13, No. 2, 2011, pp. 240-245. http://dx.doi.org/10.1590/S1516-05722011000200018

[10] J. P. Anthony, L. Fyfe and H. Smith, "Plant Active Components-A Resource for Antiparasitic Agents?” Trends Parasitology, Vol. 21, No. 10, 2005, pp. 462-468. http://dx.doi.org/10.1016/j.pt.2005.08.004

[11] D. Engels and L. Savioli, "Reconsidering the Underestimated Burden Caused by Neglected Tropical Diseases," Trends in Parasitology, Vol. 22, No. 8, 2006, pp. 363-366. http://dx.doi.org/10.1016/j.pt.2006.06.004

[12] G. F. Santoro, M. G. Cardoso, L. G. Guimarães, L. Z. Mendonça and M. J. Soares, “Trypanosoma cruzi: Activity of Essential Oils from Achillea millefolium L., Syzygium aromaticum L. and Ocimum basilicum L. on Epimastigotes and Trypomastigotes," Experimental Parasitology, Vol. 116, No. 3, 2007, pp. 283-290. http://dx.doi.org/10.1016/j.exppara.2007.01.018

[13] G. F. Santoro, M. G. Cardoso, L. G. Guimarães, J. M. Freire and M. J. Soares, "Anti-Proliferative Effect of the Essential Oil of Cymbopogon citratus (DC) Stapf (Lemongrass) on Intracellular Amastigotes, Bloodstream Trypomastigotes and Culture Epimastigotes of Trypanosoma cruzi (Protozoa: Kinetoplastida),” Parasitology, Vol. 134, No. 11, 2007, pp. 1649-1656. http://dx.doi.org/10.1017/S0031182007002958

[14] Agência Nacional de Vigilância Sanitária, "Farmacopeia Brasileira,” 5th Edition, Anvisa, Brasília, 2010.

[15] R. P. Adams, "Identification of Essential Oils Components by Gas Chromatography/Mass Spectroscopy," 4th Edition, Allured, Carol Stream, 2007.

[16] T. Mosmann, "Rapid Colorimetric Assay for Cellular Growth and Survival: Application to Proliferation and
Cytotoxicity Assays,” Journal Immunology Methods, Vol. 65, No. 1-2, 1983, pp. 55-63.

http://dx.doi.org/10.1016/0022-1759(83)90303-4

[17] National Committee for Clinical Laboratory Standards, "Methods for Dilution Antimicrobial Susceptibility Tests for Bacteria That Grow Aerobically: Approved Standard," 6th Edition, Clinical and Laboratory Standards Institute, Wayne, 2003.

[18] R. K. Lima, M. G. Cardoso, M. A. Andrade, P. L. Guimarães, L. R. Batista and D. L. Nelson, "Bactericidal and Antioxidant Activity of Essential Oils from Myristica fragrans Houtt and Salvia microphylla H.B.K,” Journal of the American Oil Chemists Society, Vol. 89, No. 3, 2012, pp. 523-528. http://dx.doi.org/10.1007/s11746-011-1938-1

[19] D. F. Ferreira, "Sisvar: Um Programa Para Análises e Ensino de Estatística," Revista Científica Symposium, Lavras, Vol. 6, No. 2, 2008, pp. 36-41.

[20] M. S. Ladaniya, “Citrus Fruit Biology, Technology and Evaluation,” Academic Press, San Diego, 2008.

[21] C. N. Muthaura, et al., “Antimalarial Activity of Some Plants Traditionally Used in Treatment of Malaria in Kwale District of Kenya,” Journal of Ethnopharmacology, Vol. 112, No. 3, 2007, pp. 545-551. http://dx.doi.org/10.1016/j.jep.2007.04.018

[22] S. Burt, "Essential Oils: Their Antibacterial Properties and Potential Applications in Foods-A Review," International Journal of Food Microbiology, Amsterdam, Vol. 94, No. 3, 2004, pp. 223-253. http://dx.doi.org/10.1016/j.ijfoodmicro.2004.03.022

[23] F. G. Kirbaslar, A. Tavman, B. Dulger and G. Turker, “Antimicrobial Activity of Turkish Citrus Peel Oils," $\mathrm{Pa}$ kistan Journal of Botany, Karachi, Vol. 41, No. 6, 2009, pp. 3207-3212.

[24] F. Deba, T. D. Xuan, M. Yasuda and S. Tawata, "Chemical Composition and Antioxidant, Antibacterial and Antifungal Activities of the Essential Oils from Bidens pilosa Linn. Var. Radiata," Food Control, Vol. 19, No. 4, 2008, pp. 346-352.

http://dx.doi.org/10.1016/j.foodcont.2007.04.011

[25] N. Belletti, S. S. Kamdem, G. Tabanelli, R. Lanciotti and F. Gardini, "Modeling of Combined Effects of Citral, Linalool and $\beta$-Pinene Used against Saccharomyces cerevisiae in Citrus-Based Beverages Subjected to a Mild Heat Treatment,” International Journal of Food Microbiology, Vol. 136, No. 3, 2010, pp. 283-289.

http://dx.doi.org/10.1016/j.ijfoodmicro.2009.10.030 